\title{
TRIALS OF CORTISONE ANALOGUES IN THE TREATMENT OF RHEUMATOID ARTHRITIS
}

\author{
BY
}

\author{
H. W. FLADEE, G. R. NEWNS, W. D. SMITH, AND H. F. WEST \\ Sheffield Centre for the Investigation and Treatment of Rheumatic Diseases
}

In 1954 the first report appeared of a controlled trial of aspirin versus cortisone in the treatment of early cases of rheumatoid arthritis (Medical Research Council-Nuffield Foundation Joint Committee, 1954). The trial showed that, after treatment for a year, the group receiving cortisone (mean dose $75 \mathrm{mg}$. daily) had fared no better than that receiving only aspirin. Some of the patients had had radiographs taken of their hands and feet at the start of the trial and at the end of the first year. Bone erosion was found to have advanced in both groups. The score for advance was slightly greater in the aspirin group, but the difference was not statistically significant. In a second trial of patients who had had rheumatoid arthritis for a mean duration of 7 years (Empire Rheumatism Council, 1955), the findings were essentially the same. Again the deterioration seen in serial radiographs was almost as much in the cortisone-treated group as in that receiving only aspirin.

Many research workers interested in the rheumatic diseases turned away from the study of corticosteroids at this point. To them corticosteroids were just non-specific suppressors of the inflammation arising from a disease process, and had no effect upon the rheumatoid process itself. Little importance was attached to the observation that a rheumatoid patient might respond well to a moderate dose of cortisone and subsequently lose the benefit gained while still on the same dose.

When the delta 1-2 analogues of cortisone and cortisol (prednisone and prednisolone) became available, further controlled trials were started. The first was a controlled trial of cortisone versus prednisone in rheumatoid patients who were in their second, third, or fourth year of cortisone treatment (Medical Research Council-Nuffield Foundation Joint Committee, 1957). The prednisone-treated group fared much better than the cortisone-treated group, but the significance of this finding was obscured by the relatively larger dose of prednisone given. This is well shown in Fig. 1 (opposite), which gives the mean doses, erythrocyte sedimentation rates and strengths of grip of the 21 patients fror $\vec{f}$ this Centre who took part in the trial. Had a 1 to $\$$ prednisone to cortisone dose been employed, the therapeutic superiority of prednisone, of whic $\mathrm{B}_{0}$ we are now aware, would have been apparent. Morio recently, fourteen patients from this trial who hat been kept on cortisone for a second year were transferred to prednisolone. On this occasion the dose ratio employed was 1 to 6 prednisolone t $\vec{q}$ cortisone. By the end of 6 months their meaf erythrocyte sedimentation rate (Wintrobe) ha $\widehat{\otimes}$ fallen from 24.6 to $15 \mathrm{~mm}$./hr, and their mean strength of grip had risen from 271 to $299 \mathrm{~mm}$. Hog (both hands). In the previous year, while they were on cortisone therapy, there had been no change in these indices.

The second prednisone trial was for patients wit rheumatoid arthritis of 3 to 24 months' duration who had not previously received corticosteroif therapy. The control group received analgesicos ad lib (Medical Research Council-Nuffield Foundation Joint Committee, 1959). The superiority of prednisone was quickly apparent in those of our patients (21) who were in this trial. At the end of the first year practically all the radiographs that showed a marked advance in bone erosion were found to belong to the group treated with analgesicsis Since many of these patients were receiving phenyB butazone, the question arose whether prednisono favourably affected the course of rheumatoi arthritis or whether phenylbutazone affected unfavourably. It was easy to imagine that a⿸丆. analgesic like phenylbutazone relieved a lot of paiß and thereby allowed destructive changes to proceedu more rapidly. A comparison between the advance्d in bone erosion seen during phenylbutazone therapy and aspirin therapy was therefore called for; so we reviewed the radiographic changes seen in those of our patients who received aspirin in the firse aspirin-cortisone trial, together with those in the patients who received aspirin in the second cortisoneo aspirin trial in whom the disease was of shor duration. We found that the advance in bons 


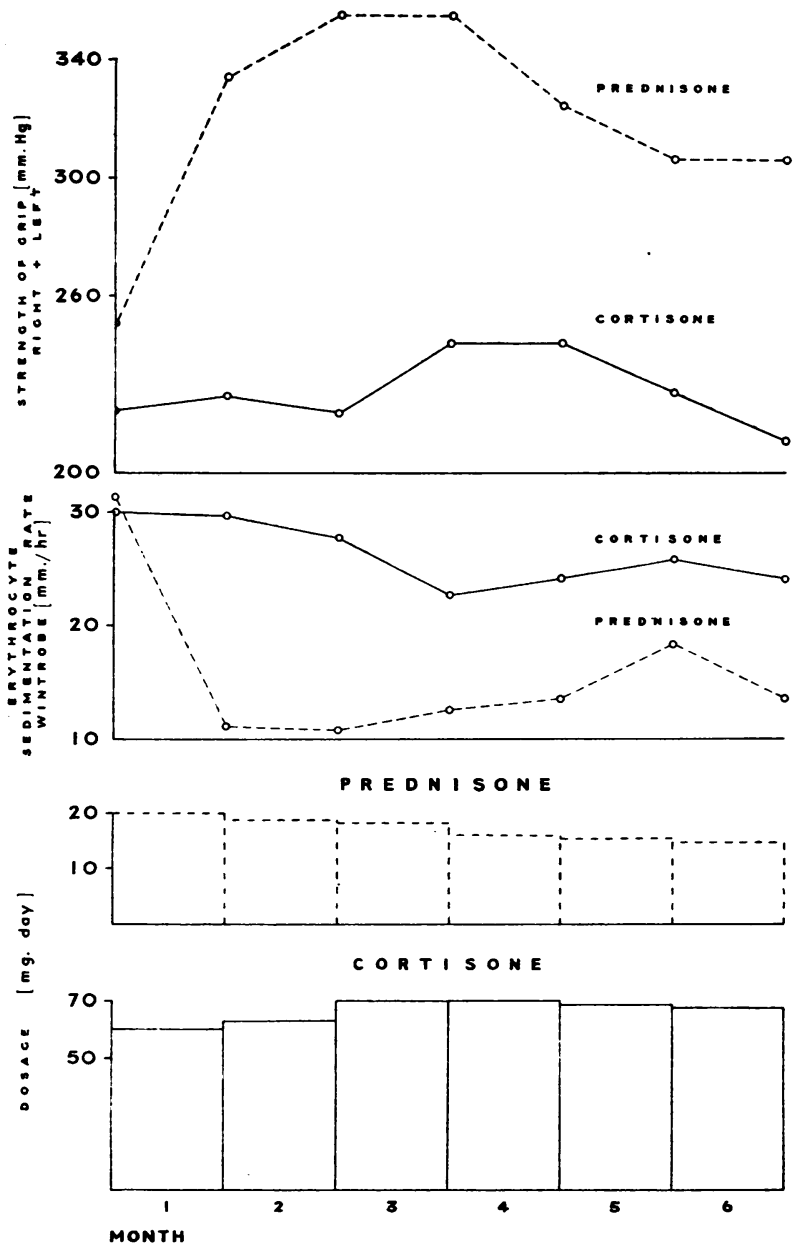

Fig. 1.-21 patients who had received cortisone for a year or more allocated at random to continue with cortisone or change to prednisone.

Mean dose, erythrocyte sedimentation rate, and strength of grip for each group for the first 6 months of the trial.

erosion during a 2-year period was of the same order as that seen in our patients who received phenylbutazone in the second prednisone trial.

Table I (overleaf) shows the present " $x$-ray score" for our patients in the second prednisone trial.* There thus remained little doubt that the slowing up, and in some cases arrest, of bone erosion in the prednisone-treated patients was due to the prednisone given.

Prednisone and prednisolone are the first substances shown to have a favourable effect on the course of rheumatoid arthritis, using objective data,

* It should be mentioned that many of the patients in the prednisone trials received prednisolone in the second and third years, since there was no evidence to suggest that prednisone and prednisolone differed qualitatively. in a fully controlled trial. Unfortunately, as is well known, they fall far short of our needs. Using the maximum safe doses for maintenance therapy, some patients with severe disease receive little relief and in the majority who do benefit the degree of benefit appears to diminish as the years go by. Further, many would say that the mean dose of prednisolone that we have used, namely $11 \mathrm{mg}$. a day, is not a safe dose. This being so, it is encumbent upon us to study each new promising cortisone analogue, in controlled trials, in the hope that one may be found that is of greater value. The questions to be asked are:

(1) Will the new analogue be effective, in a safe dose, when prednisolone has ceased to be so? 
TABLE I

RADIOGRAPHS OF SIXTEEN PAIRS OF HANDS AND FEET FROM PATIENTS IN THE ANALGESICS GROUP AND TWENTY PAIRS OF HANDS AND FEET FROM PATIENTS IN THE PREDNISONE-PREDNISOLONE GROUP GRADED BY DEGREE OF CHANGE IN BONE EROSION SEEN AFTER MEAN INTERVALS OF 30 AND 36 MONTHS RESPECTIVELY. OBSERVED CHANGES ARE EXPRESSED AS A PERCENTAGE FOR EACH GROUP.

\begin{tabular}{|c|c|c|c|c|c|c|}
\hline \multirow{3}{*}{ Therapy } & \multirow{3}{*}{$\begin{array}{c}\text { Mean } \\
\text { Interval } \\
\text { (mths) }\end{array}$} & \multicolumn{5}{|c|}{ Change in Bone Erosions (per cent.) } \\
\hline & & \multicolumn{3}{|c|}{ Advance } & \multirow{2}{*}{ No Change } & \multirow{2}{*}{ Healing } \\
\hline & & +++ & +- & $\rightarrow$ & & \\
\hline Analgesics mainly Phenylbutazone & 30 & $37 \cdot 5$ & 19 & $37 \cdot 5$ & 6 & 0 \\
\hline $\begin{array}{c}\text { Prednisone-Prednisolone (mean dose } \\
11 \mathrm{mg} .)\end{array}$ & 36 & 0 & 20 & 20 & 55 & 5 \\
\hline
\end{tabular}

(2) Will it be more effective than prednisolone ab initio?

(3) Will it maintain its effect for a longer period than prednisolone?

\section{Present Investigations}

Below are reports of some controlled trials of triamcinolone (16 hydroxy $9 \alpha$ fluoro prednisolone). It has been our experience, in the four trials mentioned above, that our own comparatively small group of participants have behaved in the same way as the total groups, so that we feel justified in drawing some conclusions from the groups of 9,17 , and 31 patients who were studied by us, and whose cases are reported in this paper.

(1) Efficacy of Triamcinolone after Prednisolone.In order to answer the first question, 34 patients suffering from rheumatoid arthritis, who had been receiving prednisolone continuously for more thaip a year, were allocated at random to continue with prednisolone or to change to triamcinolone. If order to make a fair comparison, it was necessarg to choose maximum safe dose levels for prolonged therapy for each hormone. The choice made will be considered in the discussion. Table II shows the composition of the groups after the exclusion of three patients who fell out for reasons unconnected with the trial. Certain differences were seen between the groups that may favour the triamcing olone group. A study of other similar controlles trials has shown that the overall progress reflected most clearly in the changes in the er: throcyte sedimentation rate and in the strength of grip.

TABLE II

CHARACTERISTICS OF TREATMENT GROUPS AT BEGINNING OF TRIAL

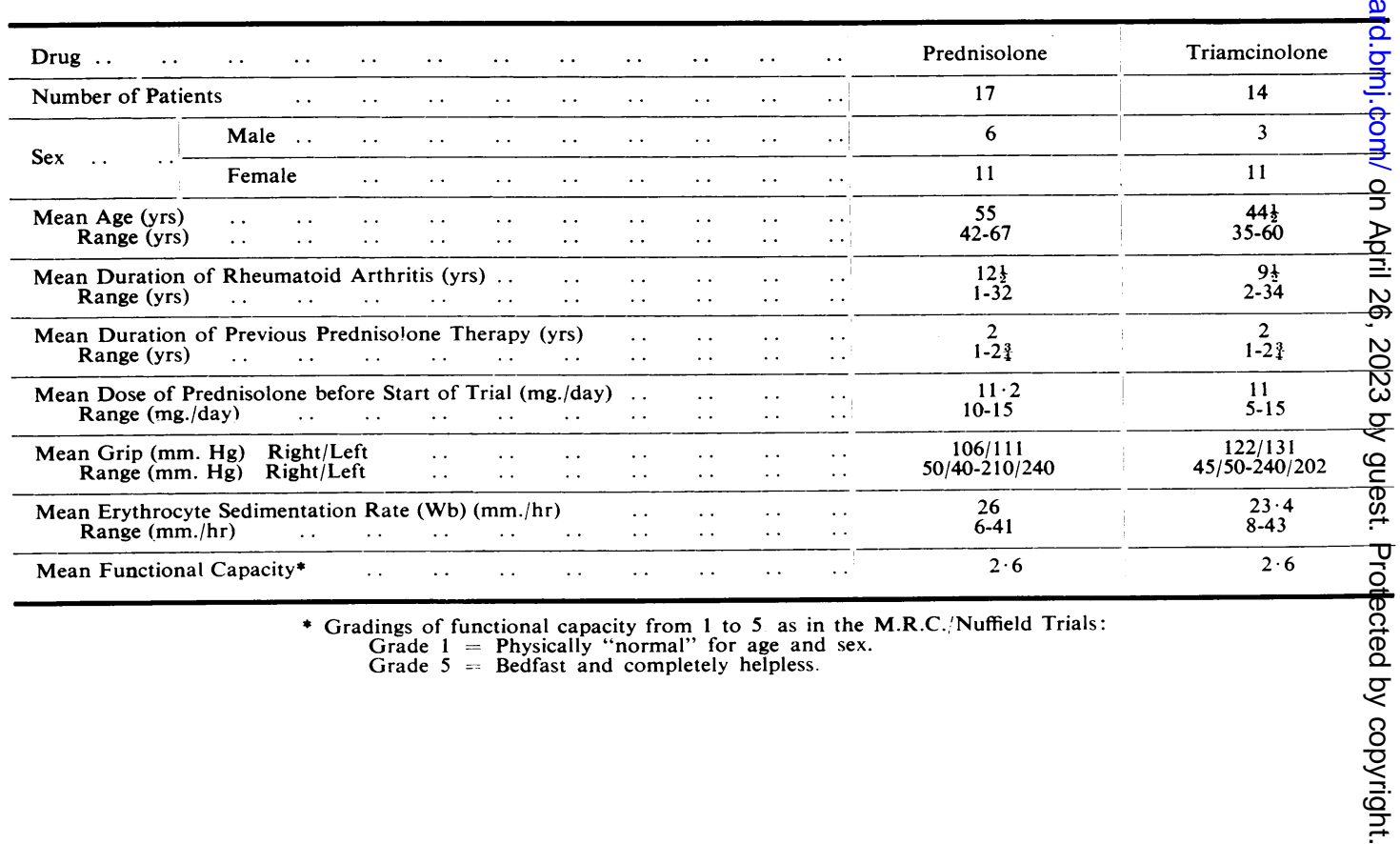


Fig. 2 shows the changes in these indices in the various groups and the mean monthly doses employed. Mean haemoglobin levels and mean white blood counts did not differ significantly. The subjective estimates went slightly in favour of triamcinolone. The assessments of functional capacity remained unchanged for the prednisolone group, but improved a little in the triamcinolone group. What may be of significance is that three of the five triamcinolone patients who showed a very definite improvement relapsed in the last 2 months. Other observations made are set out in Table III.
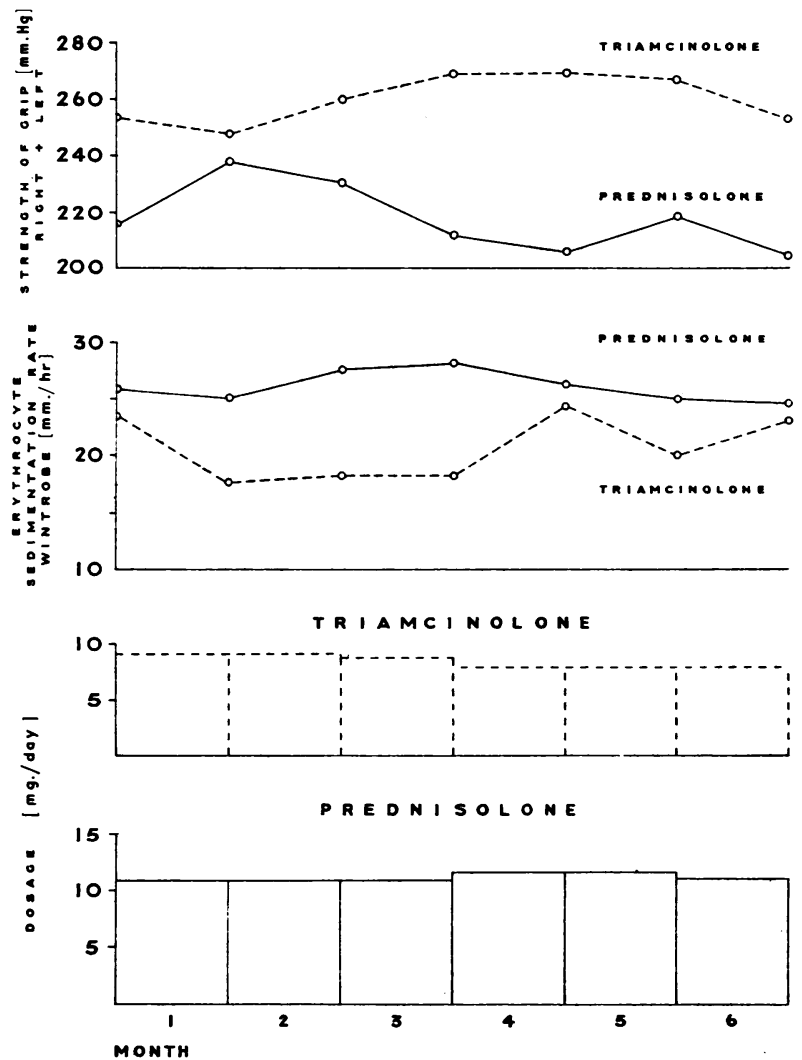

Fig. 2.-Mean monthly dose, erythrocyte sedimentation rate (Wb), and strength of grip (right hand plus left hand) for triamcinolone and prednisolone patients. The previous mean dose of prednisolone for each group is shown in Table I. The maximum grip allowed for each hand was $260 \mathrm{~mm}$. $\mathbf{H g}$.

TABLE III

CHANGES IN CERTAIN CHARACTERISTICS BETWEEN WEEK 0 AND WEEK 24 IN TWO GROUPS OF PATIENTS WHO HAD HAD PREVIOUS PREDNISOLONE THERAPY

\begin{tabular}{|c|c|c|}
\hline Observation & Drug & Changes Seen \\
\hline Weight (kg.) & $\begin{array}{l}\text { Prednisolone } \\
\text { Triamcinolone }\end{array}$ & $\begin{array}{l}\text { Rise from } 64 \cdot 5 \text { to } 66 \cdot 4 \\
\text { Fall from } 63 \text { to } 60\end{array}$ \\
\hline Mean Blood Pressure $(\mathrm{mm} . / \mathrm{Hg})$ & $\begin{array}{l}\text { Prednisolone } \\
\text { Triamcinolone }\end{array}$ & $\begin{array}{l}147 / 90 \text { to } 150 / 90 \\
149 / 89 \text { to } 148 / 89\end{array}$ \\
\hline Appetite & $\begin{array}{l}\text { Prednisolone } \\
\text { Triamcinolone }\end{array}$ & 1 up; 1 down \\
\hline Dyspepsia & $\begin{array}{l}\text { Prednisolone } \\
\text { Triamcinolone }\end{array}$ & $\left.\begin{array}{r}10 \text { at start } \\
8 \text { at start }\end{array}\right\}$ Slightly less in each group \\
\hline Sleep & $\begin{array}{l}\text { Prednisolone } \\
\text { Triamcinolone }\end{array}$ & $\begin{array}{l}2 \text { more; } 2 \text { less } \\
2 \text { more }\end{array}$ \\
\hline
\end{tabular}


TABLE IV

CHARACTERISTICS OF TREATMENT GROUPS AT START OF TRIAL

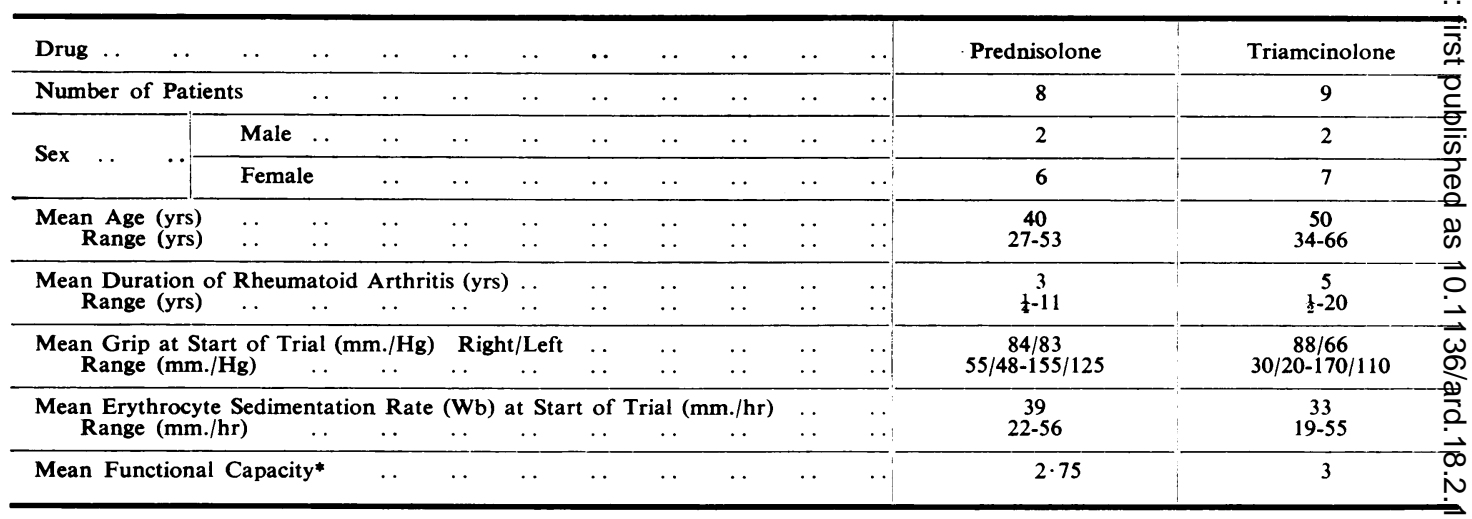

* Gradings of functional capacity are as in Table II. Grade 3 = Unemployable and able to do only a limited amount of light housework. $\vec{\bigcirc}$
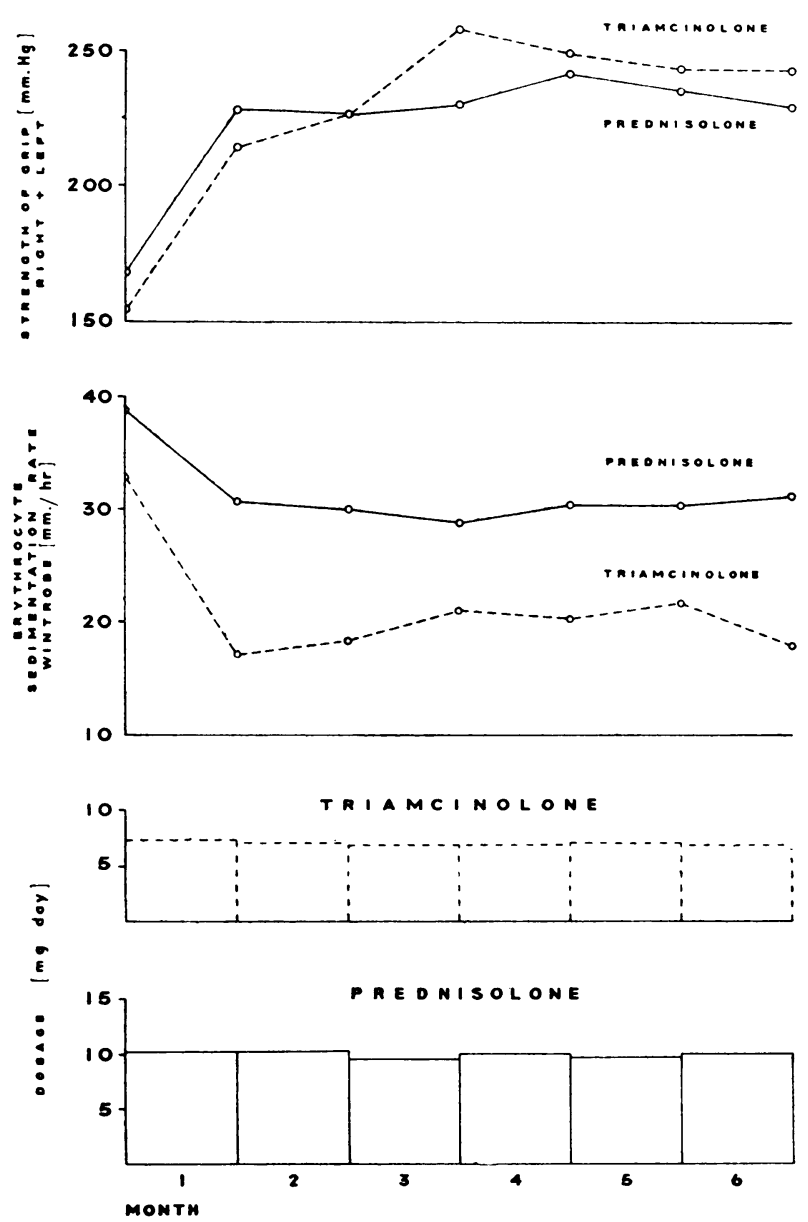

(2) Efficacy of Triamcinolone with out Previous Corticosteroids.-In the second trial, conducted in the sam $\vec{G}$ way but with patients who had res ceived no previous corticosteroid, therapy, seventeen patients were as essed monthly for 6 months. Tabro IV (above) shows the characteristics the groups at the start.

Table V (opposite) shows certaif changes in the characteristics betweeg Week 0 and Week 24.

Fig. 3 depicts the monthly mean dose erythrocyte sedimentation rate, and strength of grip.

Subjective changes were corre lated with the change in erythrocyte. sedimentation rate, the triamcinolone group showing a greater reduction in morning stiffness and more overab benefit. Although these patients

D
N
N
N
N

Fig. 3.-Mean monthly dose, erythrocyte sed mentation rate $(\mathrm{Wb})$, and strength of grip triamcinolone and prednisolone patients. All hat been receiving analgesics before the trial began. $\mathcal{D}$ 
TABLE V

CHANGES IN CERTAIN CHARACTERISTICS BETWEEN WEEK 0 AND WEEK 24 IN TWO GROUPS OF PATIENTS WHO HAD HAD NO PREVIOUS CORTICOSTEROID THERAPY

\begin{tabular}{|c|c|c|c|}
\hline Drug & $\cdots$ & Prednisolone & Triamcinolone \\
\hline $\begin{array}{l}\text { Erythrocyte Sedimentation } \\
\text { Rate (Wb) (mm./hr) }\end{array}$ & $\cdots$ & $39 \rightarrow 32$ & $33 \rightarrow 18$ \\
\hline Hb (g./100 ml.) & $\cdots$ & $13 \cdot 3 \rightarrow 14 \cdot 1$ & $12 \cdot 1 \rightarrow 14 \cdot 6$ \\
\hline Total Leucocyte Count & $\cdots$ & $8,400 \rightarrow 8,700$ & $8,000 \rightarrow 8,600$ \\
\hline Functional Capacity $\quad \ldots$ & .. & $2 \cdot 75 \rightarrow 2 \cdot 25$ & $3 \rightarrow 2$ \\
\hline Strength of Grip (mm. Hg) & $\cdots$ & $84 / 83 \rightarrow 112 / 119$ & $88 / 66 \rightarrow 116 / 125$ \\
\hline Weight (kg.) & . & $60 \rightarrow 63$ & $59 \cdot 3 \rightarrow 58 \cdot 6$ \\
\hline Blood Pressure (mm. Hg) & $\ldots$ & $133 / 79 \rightarrow 135 / 85$ & $134 / 79 \rightarrow 136 / 85$ \\
\hline
\end{tabular}

failed as a group to gain weight, four reported increased appetite and none reported a loss of appetite. The incidence of dyspepsia in each group was low.
(3) Triamcinolone and Steroid-Induced Hypertension.-Another trial was made to assess the effect of triamcinolone upon the blood pressure of patients who had become hypertensive during previous corticosteroid therapy. Freyberg, Berntsen, and Hellman (1958) found that the hypertension "often decreased" after triamcinolone administration.

Nine of our patients who had received prednisolone, or cortisone followed by prednisolone, for several years were transferred to triamcinolone and their blood pressures were recorded monthly. The mean blood pressure of the group before corticosteroid therapy was $135 / 80 \mathrm{~mm}$. $\mathrm{Hg}$; during the 6 months before the change to triamcinolone the diastolic blood pressure of each patient had risen to or exceeded $100 \mathrm{~mm}$. $\mathrm{Hg}$ at least on one occasion. Fig. 4 shows the mean blood pressure and corticosteroid dose for the 6 months before and after the change over. No fall was observed during triamcinolone therapy.
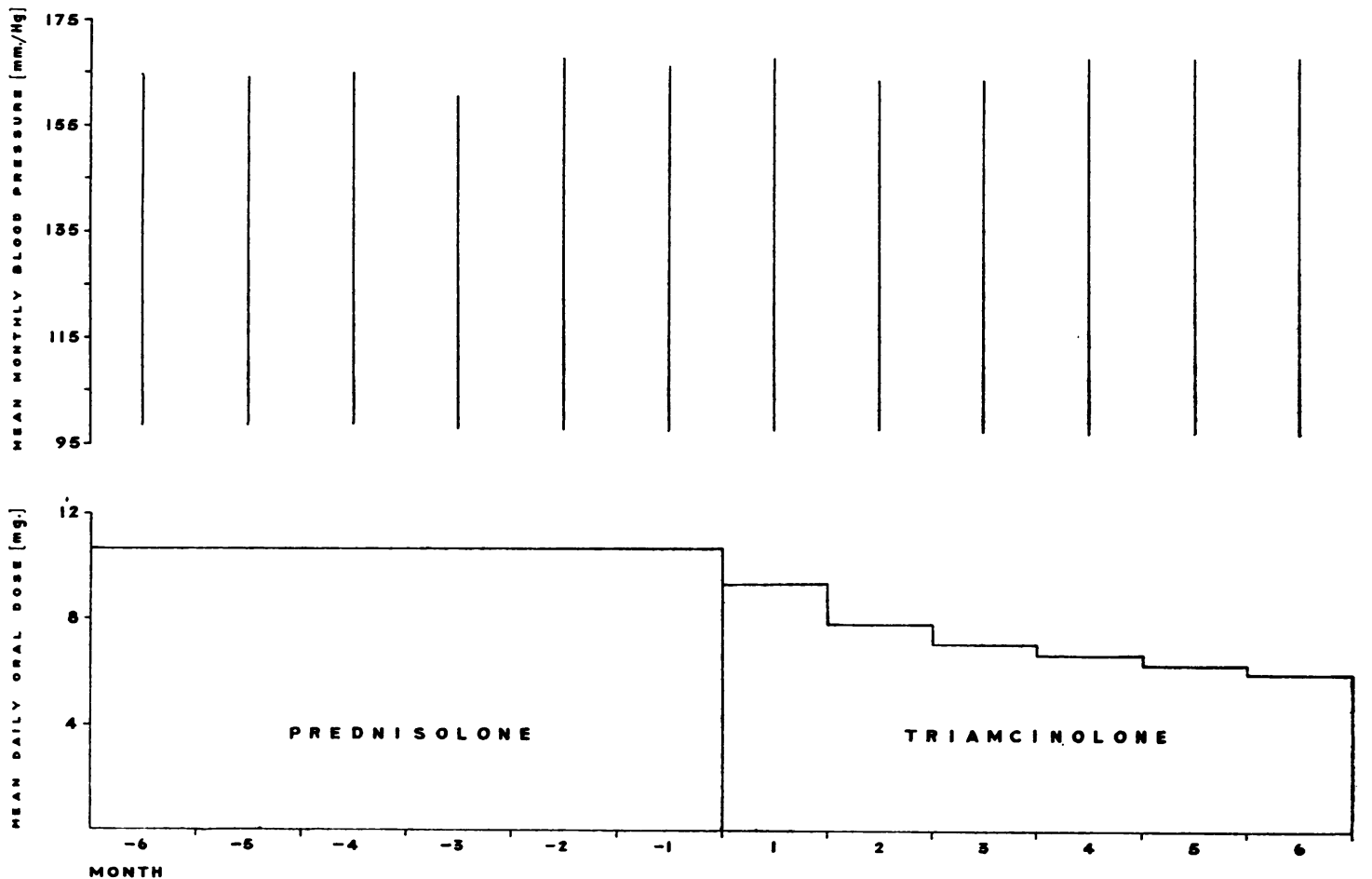

Fig. 4.-Mean blood pressure and corticosteroid dosage at monthly intervals before and after the transfer from corticosteroids to triamcinolone of nine patients whose blood pressure had risen during prolonged corticosteroid therapy. 


\section{Discussion}

As no corticosteroid yet developed cures rheumatoid arthritis, we are at present concerned with finding the cortisone analogue that in prolonged use provides the most benefit without adding disease to disease. So far no new analogue has proved, in therapeutic doses, to be free from unwanted metabolic effects. This being so, it is essential that in therapeutic trials dose levels should be chosen that can be maintained safely for long periods. The varied opinions held by those who speak from experience about the value of different corticosteroids in the treatment of rheumatoid arthritis show how important it is that the trials should be "controlled".

(1) The interpretation of the first trial reported above depends upon whether 8 to $9 \mathrm{mg}$. triamcinolone are equivalent to 11 to $12 \mathrm{mg}$. prednisolone in the production of unwanted metabolic effects. No precise tally can be made of these effects when they are mild, as in this trial. Our impression is that $9 \mathrm{mg}$. triamcinolone is certainly not less productive of unwanted effects than $12 \mathrm{mg}$. prednisolone. Both amounts are at the upper limit of what we consider a safe therapeutic dose. In our opinion the findings justify the statement, in answer to the first question, that the change from prednisolone to triamcinolone has not resulted in a renewed response of the type seen when prednisolone replaces cortisone in a 1 to 5 ratio.

(2) The second trial, which was for rheumatoid arthritic patients who had not previously received corticosteroid therapy, showed the triamcinolone group at a considerable advantage when the mean dose levels were $7 \mathrm{mg}$. triamcinolone and $10 \mathrm{mg}$. prednisolone: We were not surprised at the marked improvement seen in the triamcinolone group, but had expected to see more improvement in the prednisolone group. A comparison of the characteristics of the groups at the beginning of the trial did not suggest that the prednisolone group were likely to run a less favourable course. Some readers may be surprised at the relatively small overall improvement in the prednisolone patients in view of the common saying that 60 to 70 per cent. of rheumatoid arthritic patients improve on any form of treatment. The reason for the apparent discrepancy lies in the fact that the patients we have treated with corticosteroids were not representative of rheumatoid patients as a whole but were drawn from the 5 per cent. in whom the disease appeared to be running a severe course. This trial was made to help answer the second question. If it is agreed that the doses used were the maximum safe doses for each steroid, the answer must be that triamcinolone was more effective; but it may be that the small number of patients studied does not justify this conclusion $\Rightarrow$ This second trial is being continued in the hope that? it will contribute to an answer to the third question.

(3) The third trial was designed to study the effect of triamcinolone on cortisone- or prednisoloneinduced hypertension. Our failure to confirm the observations of Freyberg, Berntsen, and Hellmanow (1958) was caused, we think, by our use of a smaller $\overrightarrow{0}$ dose of triamcinolone. When the original 2-mg.tablet was replaced by the 4-mg. tablet, two of ourw hypertensive patients received a daily dose of 16 instead of $8 \mathrm{mg}$. The blood pressure of both patientso fell markedly, only to climb back to the hypertensive levels as the dose was gradually reduced to $8 \mathrm{mg}$ i़ In the first two trials there was no significant change in the blood pressure in either group. It will be necessary to follow triamcinolone therapy for much longer than 6 months before it can be decided whether this analogue will or will not induce hyper tension. It is, of course, only a minority of patientsD who develop hypertension during prolonged corti $\overrightarrow{0}$ sone or prednisolone treatment. When prednisolone replaced cortisone it was suggested that with less salt retention there should be less hypertensiono but this did not prove to be the case.

The only other "side-effect" encountered in thesळ" trials that calls for special comment was loss of weight.

It will be seen that, in the first trial, the triamcin 3 olone patients lost, on average $3 \mathrm{~kg}$. in 6 months This loss was approved by most patients and in the majority the fall in weight appeared to have stoppedu by the sixth month. In the trial with previouslye untreated patients there was a mean fall of $0.7 \mathrm{~kg}$ 응 in the triamcinolone patients, none of whom has experienced a decrease in appetite. Some, of course began with poor appetites. Such a group of rheumatoid arthritic patients would be below their normal weight at the start of therapy and we should expect their weight to rise as the disease subsided There have been a number of reports of gross weight loss and also of muscle wasting in patients treated with triamcinolone. The fact that we have nop seen such changes may be due to the moderate dosew level that we have used, nevertheless, the losses in weight that we have seen cannot be dismissed at necessarily harmless.

Dexamethasone.-The three questions proposed at the beginning of this paper will have to be answered for dexamethasone (16-methyl $9 \alpha$ fluorod prednisolone). Our own trial of this very interesting? hormone in patients habituated to prednisolone 
therapy is collapsing through our inability to obtain, in some patients, an anti-rheumatic effect without inducing an uncontrollable weight gain. It is not possible to study these cortisone analogues without constantly speculating as to the factors that determine their diverse properties and potencies. It seems to one of us that differences in the proteinbinding in the plasma of these hormones plays some part. Another factor, of more importance, concerns the mechanism in different tissues, and in different sites within these tissues, that determines the concentration of physiologically-active hormone available within the cells. Alterations in the configuration of the hormones appears to affect such concentrations from site to site in different degree. The physiological effects that follow no doubt depend upon the function of the particular tissue concerned.

\section{Summary}

Four controlled trials of cortisone and prednisone have been reviewed and some related data added.

Three trials of triamcinolone are reported:

Trial 1.-To assess the value of changing therapy from prednisolone to triamcinolone, 31 rheumatoid arthritic patients were studied who had been receiving prednisolone for from 1 to 3 years. They were allocated at random to continue with prednisolone or change to triamcinolone. The doses used, a mean of $11.5 \mathrm{mg}$. prednisolone and $8.5 \mathrm{mg}$. triamcinolone, were, in our opinion, at the upper limit of safety for prolonged administration for each hormone. The patients in each group were assessed at monthly intervals for 6 months. It was concluded that the slight apparent advantage gained by the triamcinolone patients was not such as to suggest that triamcinolone will favourably affect the course of rheumatoid arthritis when prednisolone has ceased to do so.

Trial 2.-Seventeen rheumatoid arthritic patients, who had not previously been treated with corticosteroids and who were deemed to belong to the 5 per cent. of rheumatoid arthritics in whom the disease runs a severe course were allocated at random to receive prednisolone or triamcinolone. The mean doses used were $10 \mathrm{mg}$. and $7 \mathrm{mg}$. respectively. These patients were studied in the same way as those in the first trial. The results showed a definite advantage for the triamcinolone patients. Over a 6-month period the doses used did not give rise to serious side-effects.

Trial 3.-Nine patients who had become mildly hypertensive during cortisone and prednisolone therapy were given triamcinolone instead; the mean blood pressure did not alter in the 6 months before and after the change in therapy.

One of us (H.F.W.) is the holder of a part-time research fellowship of the Nuffield Foundation. We also wish to thank Lederle Laboratories for a generous supply of Triamcinolone (Ledercort).

\section{REFERENCES}

Empire Rheumatism Council (1955). Ann. rheum. Dis., 14, 353. Freyberg, R. H., Berntsen, C. A., Jr., and Hellman, L. (1958). Arthrit. and Rheum., 1, 215.

Medical Research Council-Nuffield Foundation Joint Committee (1954). Brit. med. J., 1, 1223.

(1957). Ibid., 2, 199.

(1959). Ann. rheum. Dis., 18 (in the press).

Essais des analogues de la cortisone dans le traitement de l'arthrite rhumatismale

\section{RÉSUMÉ}

On passe en revue quatre essais thérapeutiques contrôlés de la cortisone et de la prednisolone et on ajoute quelques données pertinentes. On relate trois essais de la triamcinolone:

Essai I.-Pour évaluer la triamcinolone par rapport à la prednisolone administrée antérieurement, on étudia 31 malades atteints d'arthrite rhumatismale et traités par la prednisolone pendant 1 à 3 ans. On les assigna au hasard à deux groupes: l'un qui continua à recevoir de la prednisolone et l'autre qui fut transféré à la thérapie par triamcinolone. Les doses employées $(11,5 \mathrm{mg}$. de prednisolone et $8,5 \mathrm{mg}$. de triamcinolone en moyenne) furent, à notre avis, à la limite supérieure de sécurité pour l'administration prolongée de chaque hormone. Dans chaque groupe, les malades furent évalués tous les mois pendant 6 mois. On conclut que le léger avantage apparent de la triamcinolone ne fut pas suffisant pour affecter favorablement l'évolution de l'arthrite rhumatismale quand la prednisolone avait cessé d'agir.

Essai II.-On étudia 17 malades atteints d'arthrite rhumatismale et censés appartenir à ces cinq pour cent des rhumatisants chez qui la maladie suit une évolution très sévère. Aucun d'entre eux n'avait reçu de corticostéroïdes auparavant. On les assigna au hasard à recevoir soit de la prednisolone soit de la triamcinolone. Les doses moyennes furent $10 \mathrm{mg}$. et $7 \mathrm{mg}$. respectivement. Les malades furent évalués de la même manière que dans le premier essai. Les résultats accordèrent un avantage défini aux malades à la triamcinolone. Les. doses employées pendant 6 mois ne produirent pas d'effets secondaires sérieux.

Essai III.-Chez neuf malades, chez qui la tension artérielle avait monté un peu pendant le traitement par la cortisone et la prednisolone, on substitua la triamcinolone; la tension artérielle moyenne ne changea pas pendant 6 mois qui précédèrent ou se succédèrent au changement thérapeutique.

\section{Ensayos de los análogos de la cortisona en el tratamiento de la artritis reumatoide}

\section{Sumario}

Se pasan en revista cuatro ensayos terapéuticos controlados de la cortisona y de la prednisolona y se añaden algunos datos pertinentes. Se relatan tres ensayos de la triamcinolona. 
Ensayo I.-Para valorar el cambio terapéutico de la prednisolona a la triamcinolona, se estudiaron 31 enfermos con artritis reumatoide tratados con prednisolona por uno a tres años. Estos enfermos fueron repartidos al azar en dos grupos: uno que siguió con prednisolona y el otro que fué tratado con triamcinolona. Las dosis empleadas (11,5 mg. prednisolona y 8,5 triamcinolona en promedio) aproximáronse, a nuestro juicio, a los límites superiores de seguridad para la administración prolongada de cada hormona. En ambos grupos los enfermos fueron valorados cada mes durante seis meses. Se llegó a la conclusión de que la pequeña ventaja aparente de la triamcinolona no fué suficiente para afectar favorablemente la evolución de la artritis reumatoide, cuando la prednisolona había cesado de actuar.

Ensayo II.-Se estudiaron 17 enfermos con artritis reumatoide, perteneciendo aparentemente a aquel cinco por ciento de los reumáticos en que la enfermedad sigue una evolución muy severa. Ninguno de ellos había. recibido corticoesteroides anteriormente. Se les asignø? al azar al tratamiento sea con prednisolona, sea cor triamcinolona. Las dosis medias fueron de $10 \mathrm{mg}$. de $7 \mathrm{mg}$. respectivamente. Los enfermos fuero valorados del mismo modo que en el primer ensayō Los resultados fueron netamente mejores en los enfermo tratados con triamcinolona. Las dosis empleada durante seis meses no produjeron efectos secundarios serios.

Ensayo III.-Triamcinolona fué administrada a nueve. enfermos en los cuales la tensión arterial había subid $\odot$ algo durante un tratamiento previo con cortisona $\overrightarrow{\boldsymbol{\sigma}}$ prednisolona. No se observó cambio alguno de lâ tensión arterial media en estos enfermos seis meses antes o después de cambiar el tratamiento. 